NASA

Technical Memorandum105656
1437

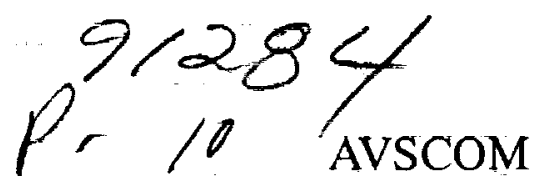

Technical Report $91-\mathrm{C}-033$

\title{
Effect of Lubricant Jet Location on Spiral Bevel Gear Operating Temperatures
}

\section{Robert F. Handschuh}

Propulsion Directorate

U.S. Army Aviation Systems Command

Lewis Research Center

Cleveland, Ohio

3

(NASA-TM-105656) EFFECT OF LUBRICANT JET LOCATION ON SPIRAL BEVEL GEAR OPERATING TEMPERATURES (NASA) 10 p
N92-26106

Unclas

$63 / 37 \quad 0091284$

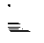

Prepared for the

Sixth International Power Transmission and Gearing Conference sponsored by the American Society of Mechanical Engineers Phoenix, Arizona, September 13-16, 1992 
EFFECT OF LUBRICANT JET LOCATION ON SPIRAL BEVEL GEAR

\author{
OPERATING TEMPERATURES \\ Robert F. Handschuh \\ Propulsion Directorate \\ U.S. Army Aviation Systems Command \\ Lewis Research Center \\ Cleveland, Ohio $\mathbf{4 4 1 3 5}$
}

\section{ABSTRACT}

An experimental study was conducted to determine the effect of lubricant jet location on spiral bevel gear bulk temperatures. Transient surface temperatures were also measured. Tests were conducted on aircraft quality spiral bevel gears in a closed-loop test facility. Thermocoupled pinions and an infrared microscope were used to collect the pertinent data. A single fan jet lubricated the test gears.

Lubricant flow rate (lubricant jet pressure) and applied torque were also varied. The results of this study showed that jet placement had a significant effect on the gear bulk temperatures.

\section{INTRODUCTION}

The lubrication of gears is a key parameter when developing a transmission design. A lubricant must not only protect the surfaces that are transmitting load, by a thin film, but also must provide the necessary cooling. Depending on the given speed, load, and service conditions the gears may be lubricated by many means. In a very low-speed, open sump requirement, grease may be the best solution. In automotive systems (e.g., rear axle or differential), gears are submerged in a wet sump and oil is distributed by splash. For aerospace applications the lubrication system typically uses jet spray and is operated in a dry sump mode. Jet spray and dry sump operation offer the best conditions for gear mesh efficiency while providing the necessary lubrication and cooling.

Typically the lubrication problem for spiral bevel gears has been solved by assuring an adequate flow of lubricating oil. While in principal this appears to be a prudent approach, an unnecessary penalty may be being paid through unnecessary churning and pumping of the excess oil.

Research on lubricant jet placement for parallel axis gears has been done by several investigators (Akin et al., 1975; Doi et al., 1981; and Townsend and Akin, 1981). Also the transient nature of heat input due to gear meshing and contacting bodies has been studied (Turchina et al., 1974 and Nieman and Lechner, 1965). Only a few investigators however, have studied the lubrication of spiral bevel gears. Chao et al. (1981) utilized the gear geometry effects combined with lubricant properties and dynamic load to estimate surface temperature rise. None of the above studies were intended to pursue an in-depth investigation of lubricant jet placement effects on spiral bevel gear operating temperature.
The purpose of this paper is to document the effects of jet placement, and variation in lubrication flow rate (pressure) on the steady-state temperatures of aircraft quality spiral bevel gears. Also a brief investigation of the transient measurement of surface temperature will be presented. A series of tests were conducted. Test facility power was varied along with the lubrication system variables. An instrumented spiral bevel pinion was used for the steadystate thermocouple measurements. An infrared microscope was used for the transient surface temperature measurements.

\section{TEST FACILITY}

A sketch of the test facility used for the study to be discussed is shown in Fig. 1. This facility used a closed loop system to provide the required load. A crosssectional view with the major components is shown in Fig. 2. A helical gear mesh connects the spiral bevel gear shafts. One helical gear is connected by v-belts to the drive motor. The other helical gear is moved axially by a thrust piston to apply the required loop torque. A slip coupling provides an initial loop preload. Test facility operational parameters are shown in Table I. Design data of the spiral bevel gear test hardware is shown in Table 2. Lubricant nominal properties (Townsend, 1990) are shown in Table 3.

The test hardware was lubricated by a single fan jet. The jet was positioned at a constant distance from the tooth top such that the fan width equaled the face width of the test hardware at the tooth top land. The fan jet design and positioning with respect to the test hardware is shown in Fig. 3 for three of the five nozzle locations chosen. At these three locations the nozzle was positioned a given distance (Fig. 3) and oriented tangent to the spiral angle of the gear teeth. At the into-mesh or out-of-mesh locations the jet sprayed directly into the wedge area between the meshing teeth. The positions were chosen based on current lubrication practices as well as locations that permitted use of the infrared microscope. At into-mesh and out-of-mesh locations the infrared microscope could not be used. This was due to the large amount of lubricant splash into the line of sight of the infrared signal from the gear teeth.

An instrumented pinion used for the test measurements is shown in Fig. 4. The thermocoupled pinion is connected to a laboratory computer via a slip ring. A total of five thermocouples were used to measure the temperatures at four different locations at each desired test condition. Four thermocouples (top, toe, and two on 


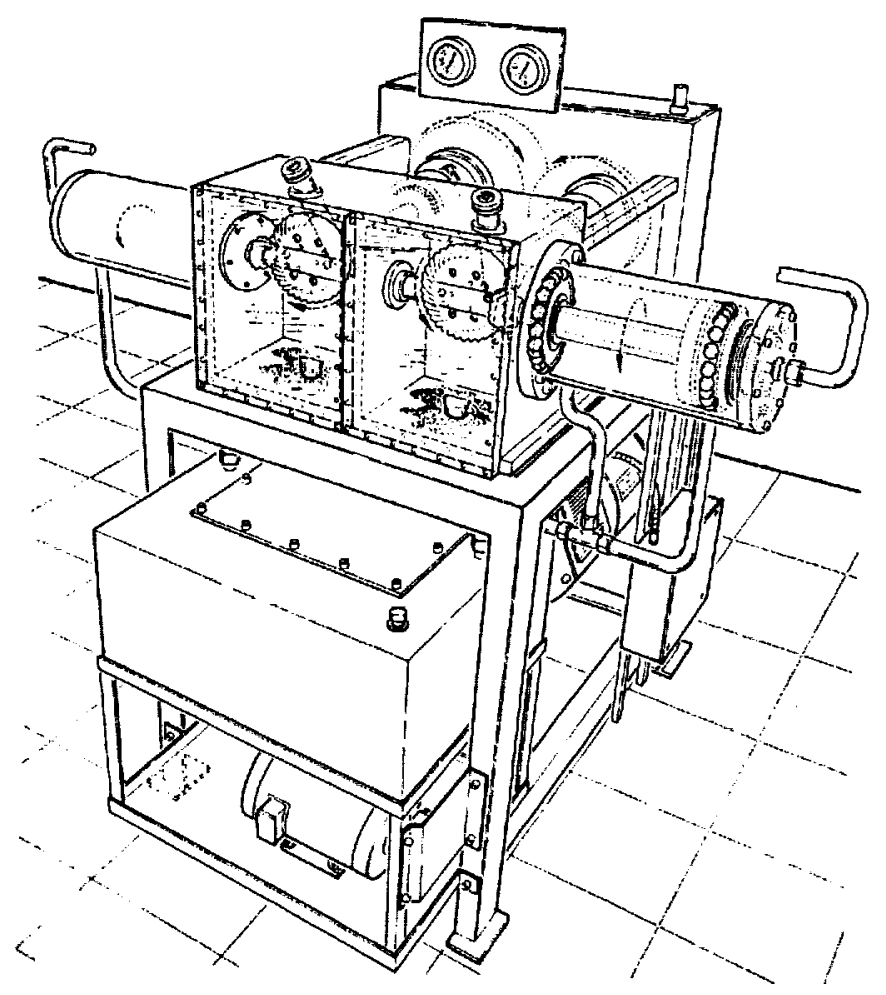

Figure 1.-Sketch of spiral bevel test facility.

TABLE I.-SPIRAL BEVEI, GEAR TEST FACILITY PARAMETERS (100 PERCENT CONDITIONS)

Pinion shaft speed, $\mathrm{rpm} \ldots \ldots \ldots \ldots \ldots \ldots \ldots \ldots 14400$

Pitch line velocity, $\mathrm{m} / \mathrm{sec}(\mathrm{ft} / \mathrm{min}) \ldots \ldots \ldots \ldots 44.7(8803)$

Pinion shaft power, $k W(\mathrm{hp}) \ldots \ldots \ldots \ldots \ldots \ldots 57$ (720 hp)

Test section flow rate $\max \mathrm{cm}^{3} / \mathrm{sec}(\mathrm{gpm}) \ldots \ldots \ldots .51(0.8)$

Oil inlet temperature, ${ }^{\circ} \mathrm{C}\left({ }^{\circ} \mathrm{F}\right) \ldots \ldots \ldots \ldots \ldots \ldots 38(100)$

Oil pressure $\max , \mathrm{MPa}(\mathrm{psi}) \ldots \ldots \ldots \ldots \ldots \ldots 1.38(200)$

\section{TABLE II.-TEST SPECIMEN DESIGN PARAMETERS}

Number of teeth pinion/gear $\ldots \ldots \ldots \ldots \ldots \ldots \ldots 12 / 36$

Diametral pitch . . . . . . . . . . . . . . 5.141

Mean spiral angle $\ldots \ldots \ldots \ldots \ldots \ldots \ldots \ldots \ldots \ldots \ldots \ldots \ldots \ldots 5^{\circ}$

Mean cone distance, $\mathrm{mm}$ (in.) $\ldots \ldots \ldots \ldots \ldots .81 .1$ (3.191)

Face width, mm (in.) . . . . . . . . . 25.4 (1.0)

Nominal pressure angle, deg $\ldots \ldots \ldots \ldots \ldots \ldots \ldots 22.5$

Shaft angle, $\operatorname{deg} \ldots \ldots \ldots \ldots \ldots \ldots \ldots \ldots \ldots \ldots$

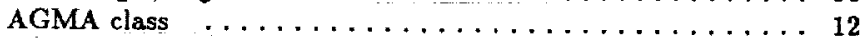

AGMA bending stress index, MPA (ksi) . . . . . 398 (57.7)

AGMA contact stress index, MPA (ksi) $\ldots \ldots \ldots \ldots 2406$ (349)

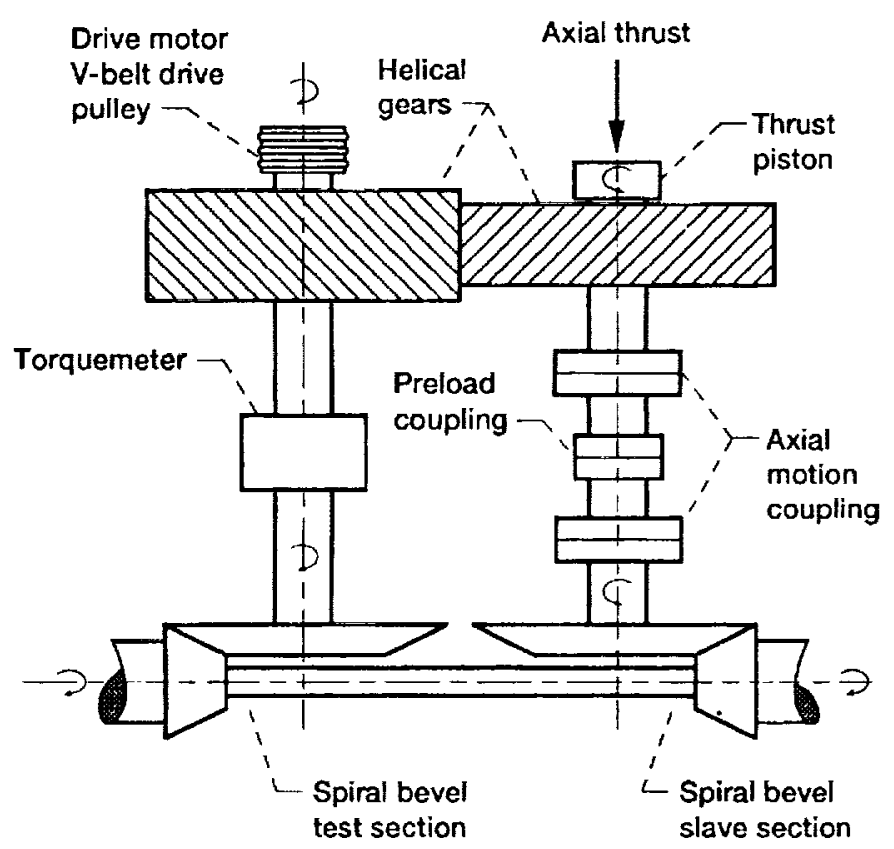

Figure 2.-Crossectional view of facility.

TABLE III.-NOMINAL LUBRICANT PROPERTIES

Lubricant, synthetic paraffinic oil plus additive. Additive: 5 percent by volume (phosphorus, 0.03 vol $\%$ sulfur, 0.93 vol\%].

Kinematic viscosity, $\mathrm{cm}^{2} / \mathrm{sec}(\mathrm{cS})$ at:

$244 \mathrm{~K}\left(-20^{\circ} \mathrm{F}\right) \ldots \ldots \ldots \ldots \ldots \ldots 2500 \times 10^{-2}(2500)$

$311 \mathrm{~K}\left(100^{\circ} \mathrm{F}\right) \quad \ldots \ldots \ldots \ldots \ldots \ldots \ldots \ldots 31.6 \times 10^{-2}(31.6)$

$372 \mathrm{~K}\left(210^{\circ} \mathrm{F}\right) \ldots \ldots \ldots \ldots \ldots \ldots \ldots \ldots .5 .5 \times \ldots \ldots 0^{-2}(5.5)$

$477 \mathrm{~K}\left(400^{\circ} \mathrm{F}\right) \quad \ldots \ldots \ldots \ldots \ldots \ldots \ldots \ldots, 2.0 \times 10^{-2}(2.0)$

Flash point, $K\left({ }^{\circ} \mathrm{F}\right) \quad \ldots \ldots \ldots \ldots \ldots \ldots \ldots \ldots(455)$

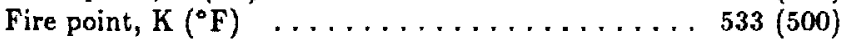

Pour point, $K\left({ }^{\circ} \mathrm{F}\right) \ldots \ldots \ldots \ldots \ldots \ldots \ldots \ldots \ldots . \ldots \ldots$. $19(-65)$

Specific gravity $\ldots \ldots \ldots \ldots \ldots \ldots \ldots \ldots \ldots . \ldots \ldots . \ldots \ldots$

Vapor pressure at $311 \mathrm{~K}\left(100^{\circ} \mathrm{F}\right)$ torr $\ldots \ldots \ldots \ldots .0 .1$

Specific heat $311 \mathrm{~K}\left(100^{\circ} \mathrm{F}\right)$,

$\mathrm{J} / \mathrm{kg} \mathrm{K}\left(\mathrm{Btu} / \mathrm{lb}^{\circ} \mathrm{F}\right) \ldots \ldots \ldots \ldots \ldots(0.523)$ 


\section{ORIGINAL PAGE \\ BLACK AND WHITE PHOTOGRAPH}

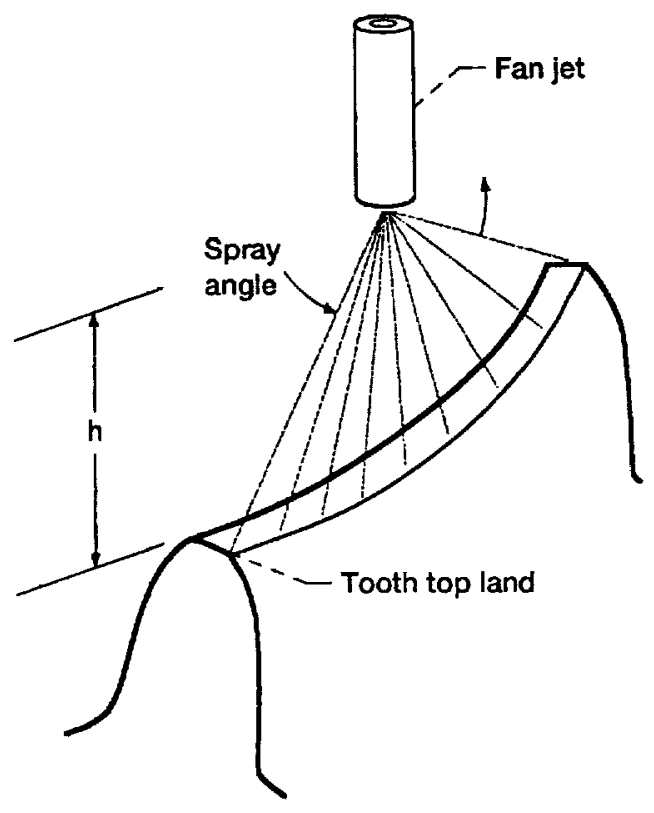

\begin{tabular}{|lc|}
\hline Distance $h,{ }^{* *}$ & $10.2 \mathrm{~mm}(0.4 \mathrm{in})$. \\
\hline Equivalent orifice diameter & $1.09 \mathrm{~mm}(0.043 \mathrm{in})$. \\
\hline Flow capacity (water) $^{*}$ & $42 \mathrm{~cm}^{3} / \mathrm{s}(0.67 \mathrm{gpm})$ \\
\hline Spray angle* $^{*}$ & $90^{\circ}$ \\
\hline
\end{tabular}

* Based on $1.38 \mathrm{MPa}(200 \mathrm{psi})$ at jet

* Distance perpendicular to tooth top land

Figure 3.-Fan jet design used in the test program.

the heel) were placed below the tooth surface approximately $0.76 \mathrm{~mm}$ $(0.03$ in.). The root thermocouple was just bonded to the surface. Thermocouples at the top and root were located at half the face width. Thermocouples at the toe and heel were located at approximately one-half the tooth height and centered between the concave and convex sides of the tooth. The locations for this instrumentation are shown on Fig. 5. Thermocouple locations were chosen to provide temperature information at several locations of the tooth body. At these locations there was no danger of losing the thermocouples due to surface interaction between the meshing teeth. Along with the steady-state thermocouple measurements, transient surface temperature measurements were made using an infrared microscope. This instrument, depicted in Fig. 6 uses an Indium Antimonide sensor, cooled with liquid nitrogen (Barnes Engineering Co., 1982).

The microscope has an effective measurement spot size equal to $0.51 \mathrm{~mm}(0.020 \mathrm{in}$.), based on the focal length of the lens arrangement used. The sensor is sensitive to infrared radiation in the 1 to $10 \mu \mathrm{m}$ range. The radiance (infrared radiation) of the target is assessed and related to a temperature based on the instrument's calibration.

\section{INSTRUMENTATION AND CALIBRATION}

\section{Thermocouples}

The instrumented pinion shown in Fig. 4 was used along with a slip ring assembly and portable laboratory computer to make the steady-state thermocouple measurements. Before installation in the test facility, the assembly was connected as it would be used during testing. Three known temperatures (that of an ice water bath, room

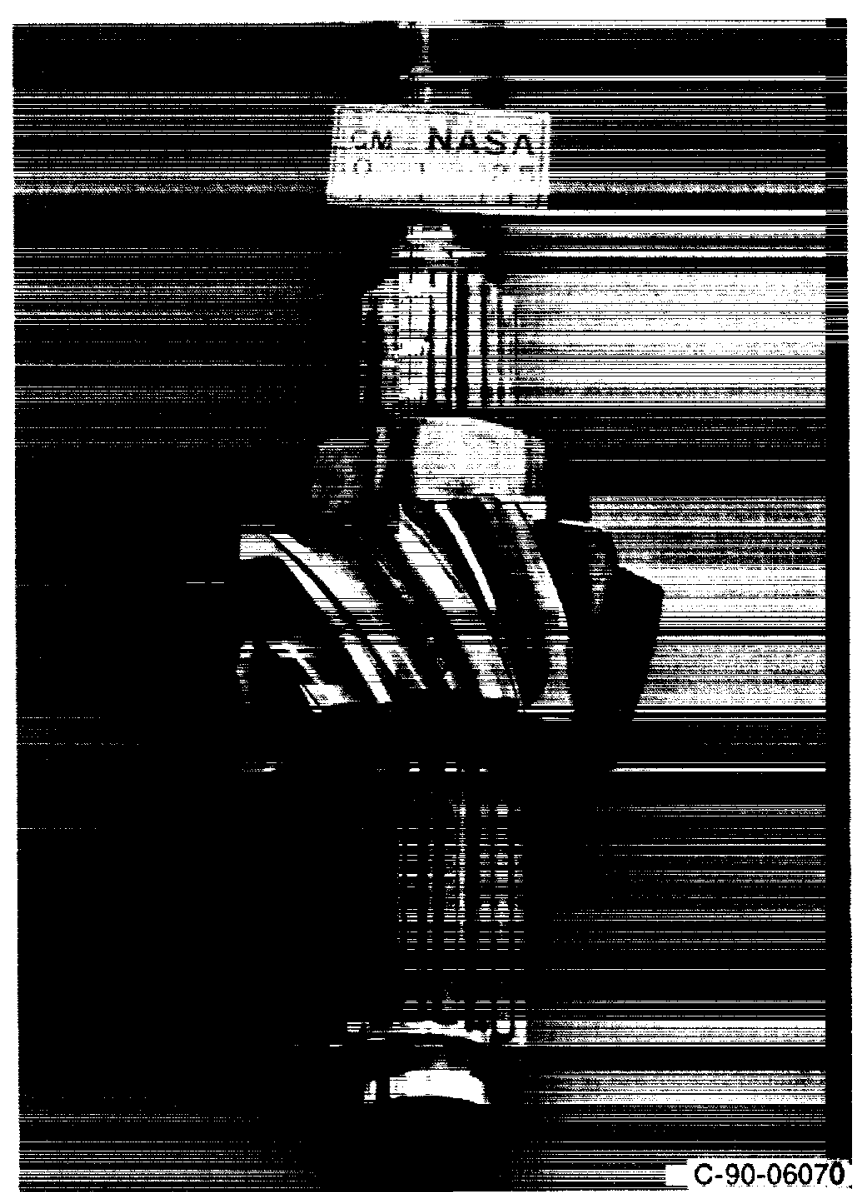

Figure 4._Photograph of instrumented spiral bevel pinion.

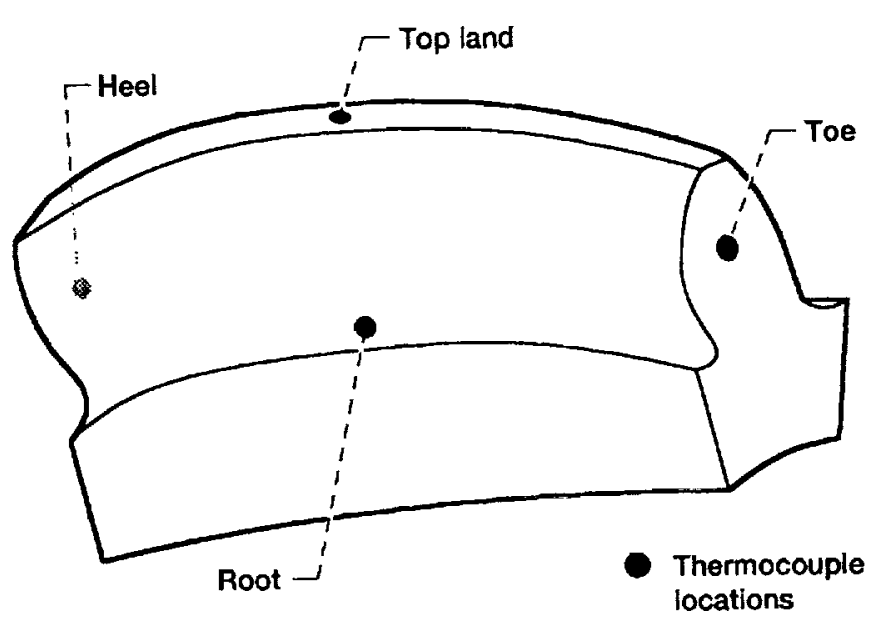

Figure 5.-Thermocouple locations on test pinion. 


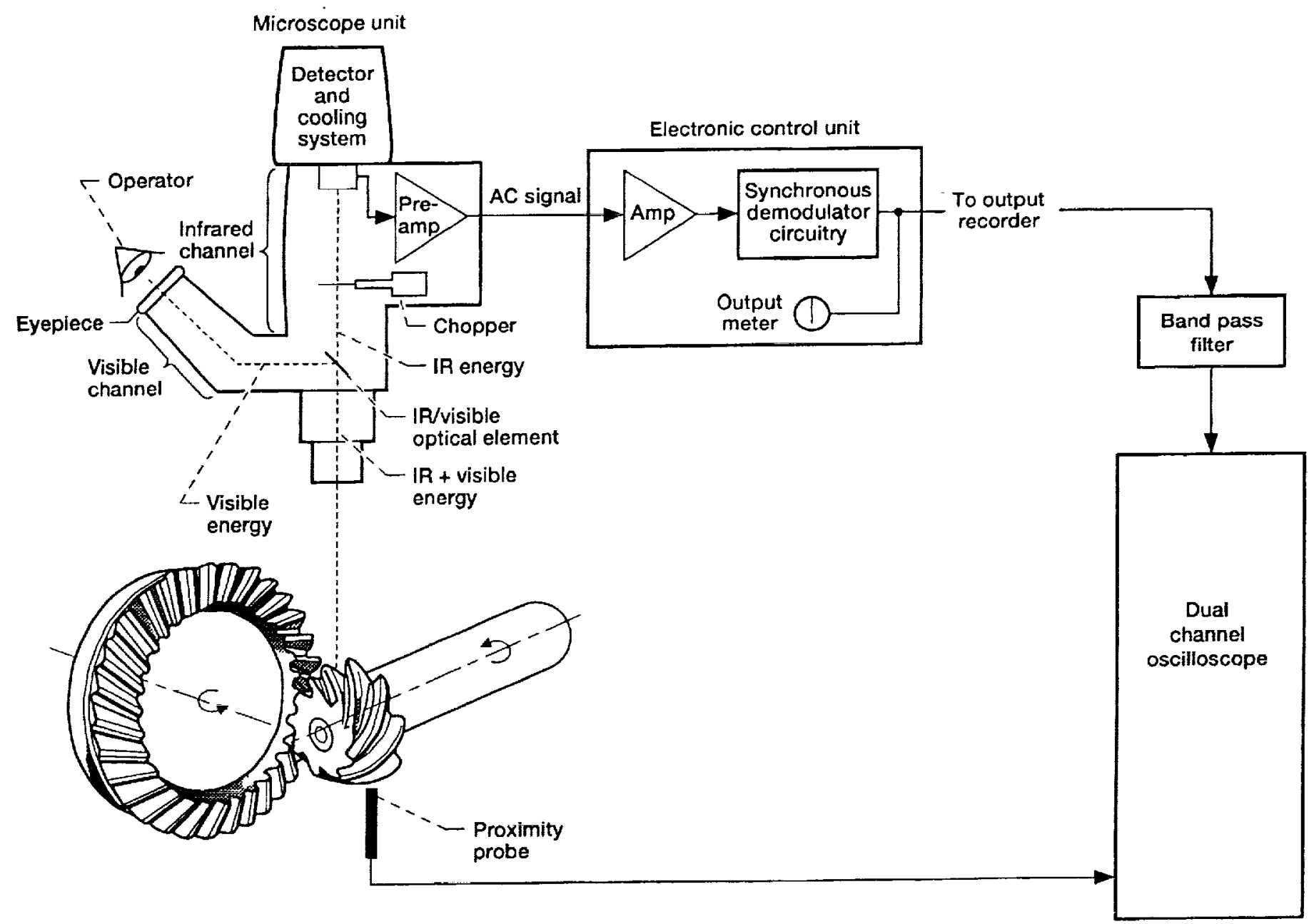

Figure 6.-Transient temperature measurement system.

temperature, and boiling water) were used for reference to test the measurement system without any rotation of the pinion shaft. At these three temperatures the instrumented pinion's thermocouples produced results within $0.6^{\circ} \mathrm{C}\left(1.0^{\circ} \mathrm{F}\right)$ of the expected reading.

\section{Infrared Microscope}

The calibration of the infrared system used in the experiments is quite a bit more complex than that of the instrumented pinion. Several items that influenced the test results needed to be simulated in the calibration tests. Items such as surface emissivity and oil film thickness effects on the gear must be included in the calibration. Calibration tests had to be conducted for both steady-state and transient modes of instrument operation and for a black-body source as well as for the gear material (with and without the test lubricant). Also the effect of the sapphire lens, used in the test facility, that stands in the optical path between the microscope and the test hardware had to be included in the calibration.

The steady-state calibration was accomplished by heating a black-body source (instrument manufacturer's calibration source) or gear material source. Using the gear material source required measuring the temperature using a thermocouple at the surface. At the same time the lens material was put within the optical path. Measurements were taken with and without the lens. Also the effect of oil film was investigated. Oil was delivered to the gear material calibration dish by a syringe. The oil film thickness was determined from the volume difference in the syringe.

The transient temperature calibration was conducted using a mechanical shutter. The shutter was rotated in the optical path and thereby provided a temperature differential between the shutter and the gear material dish or the black-body source. The surface temperature and the transient voltage were measured. In this manner the surface temperature differential was known as a function of voltage differential. These calibrations were used to access the infrared data that will be described later.

\section{TEST PROCEDURE}

Once the oil-jet location was selected and set, the test conditions (shaft speed and loop torque) were typically set and maintained throughout the test. A typical start-up and operation of the facility is shown in Fig. $\overline{7}$, where the thermocouple temperatures are plotted as a function of run time. During a typical test all thermocouples would be stabilized before any transient or steady-state data was acquired. As shown in Fig. 7 this would take approximately 10 min. Once all data was taken at a given set of conditions, the conditions were altered and the procedure repeated. 


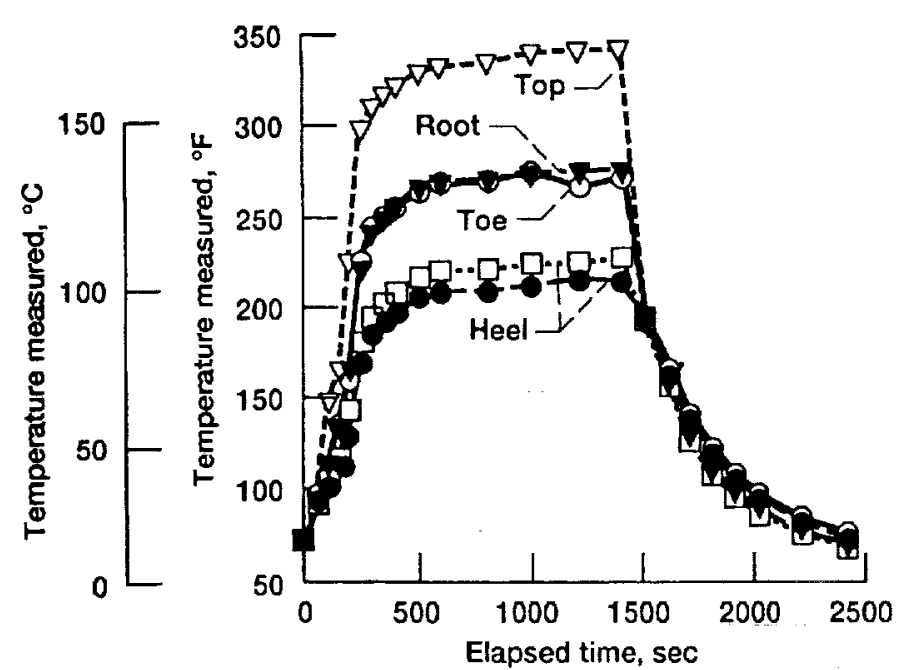

Figure 7.-Typical bulk temperature, time history of a test.

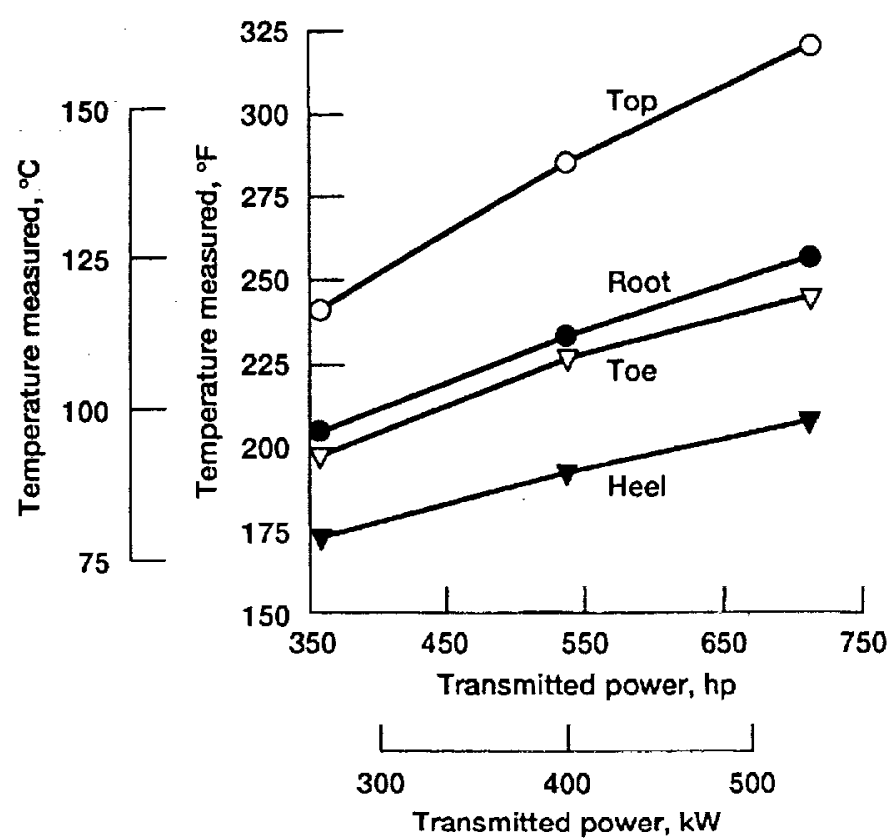

Figure 8.-Effect of load on pinion tooth temperatures at three power levels. All data taken at $38^{\circ} \mathrm{C}\left(100^{\circ} \mathrm{F}\right)$ oil inlet temperature and $14400 \mathrm{rpm}$ pinion shaft speed.

\section{STEADY-STATE RESULTS}

The effects of transmitted power, lubricant flow (pressure), oil jet location, and run time on the pinion temperature were determined. Oil inlet temperature was kept constant for all tests at $38{ }^{\circ} \mathrm{C}\left(100^{\circ} \mathrm{F}\right)$. The same fan jet nozzle was used in all tests, so varying oil supply pressure varied the resultant flow rate of the lubricant.

The effect of transmitted power on the steady-state operating temperatures is shown in Fig. 8. Pitch line velocity remained constant while the level of torque was varied. Three power levels 266 to $531 \mathrm{~kW}$ ( 357 to $712 \mathrm{hp}$ ) were tested. The oil jet was positioned on the gear $90^{\circ}$ before mesh. This data indicated that increasing the load caused the measured temperatures to increase.
The variation in pinion temperature as a function of lubricant flow rate is presented in Fig. 9. All these tests were conducted at $532 \mathrm{~kW}(713 \mathrm{hp})$, and $14400 \mathrm{rpm}$ pinion rotational speed. The oil jet was located on the gear $80^{\circ}$ out of mesh. Increasing the flow of lubricant caused a decrease in the pinion temperature over the range of flows tested.

The effect of lubricant jet location on the pinion temperature was investigated, using five different jet locations as indicated in Fig. 10. All data was gathered with the loop load at $532 \mathrm{~kW}(713 \mathrm{hp})$ and at a constant shaft speed. Two different lubricant flow rate conditions were tested at each location. As can be seen from the

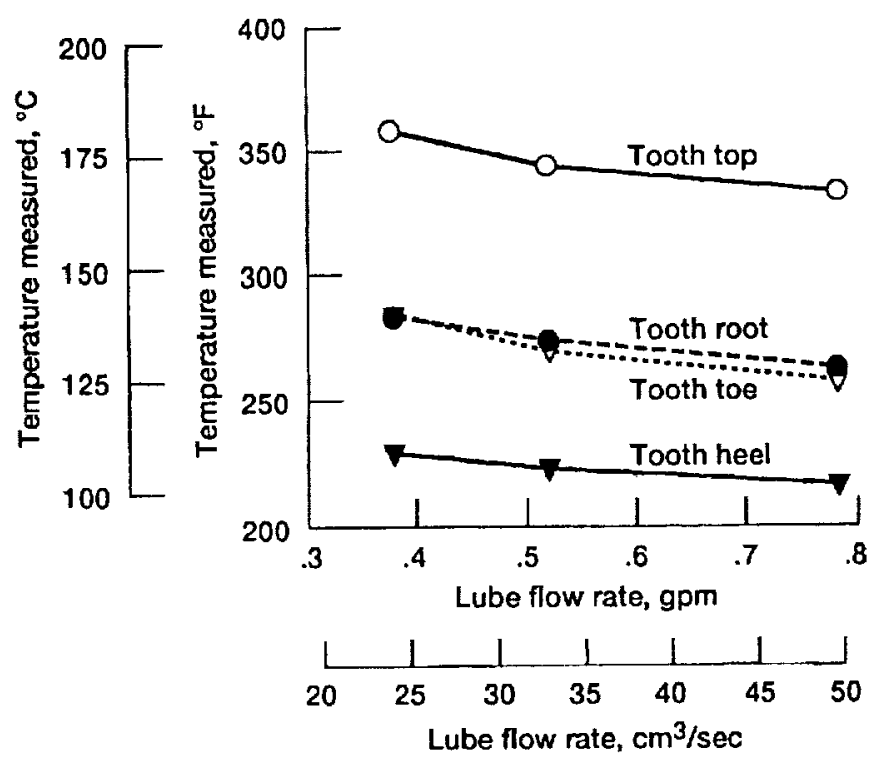

Figure 9.--Effect of flow rate on tooth temperature after $625 \mathrm{~min}$ of operation. Lubricant pressure varied from $0.35-1.42 \mathrm{MPa}$ (51-206 psi)

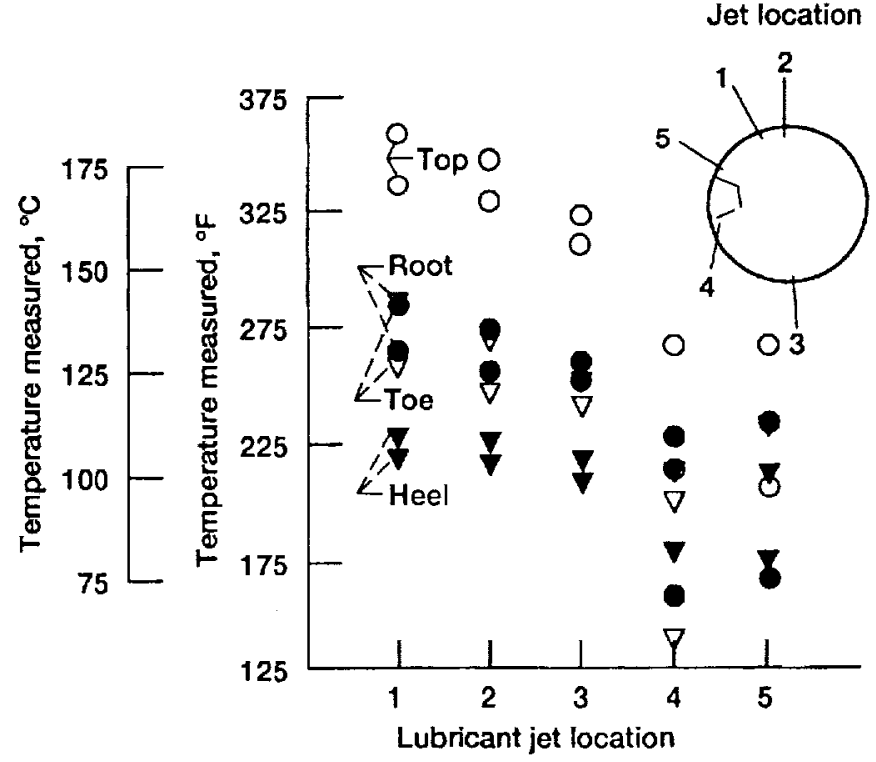

Figure 10.-Effect of lubricant jet location on pinion thermocouple measurements for two flow rates at 526-538 kW (705-721 hp). Upper symbol is for $24 \mathrm{~cm}^{3} / \mathrm{sec}$ ( $0.38 \mathrm{gpm}$ ) and lower symbol is for $49 \mathrm{~cm}^{3} / \mathrm{sec}(0.77 \mathrm{gpm})$. 
data, both into-mesh and out-of-mesh positions gave the lowest pinion operating temperatures. Since no thermal benefit was attained by lubricating into mesh, out-of-mesh lubrication would be chosen. Lubrication at this location would not incur the oil pumping losses that the into-mesh condition would cause.

The effect of run time on pinion temperature is shown in

Fig. 11. The same set of operating conditions as shown in Fig. 11 were repeated at four different elapsed times during the duration of the described test program for the same instrumented pinion. The oil jet was positioned $80^{\circ}$ out of mesh on the gear. As can be seen from the figure, there is a given time where the gears operate at a higher temperature. The temperature decreases as the gears are wearing in. Only one thermocouple did not follow this trend and was located at the tooth toe position. The tooth temperature measured at the tooth top decreased about $14^{\circ} \mathrm{C}\left(25^{\circ} \mathrm{F}\right)$ with smaller temperature drops at the other locations. After about $10 \mathrm{hr}$ of operation the gears appeared to have reached a point where any further change was small.

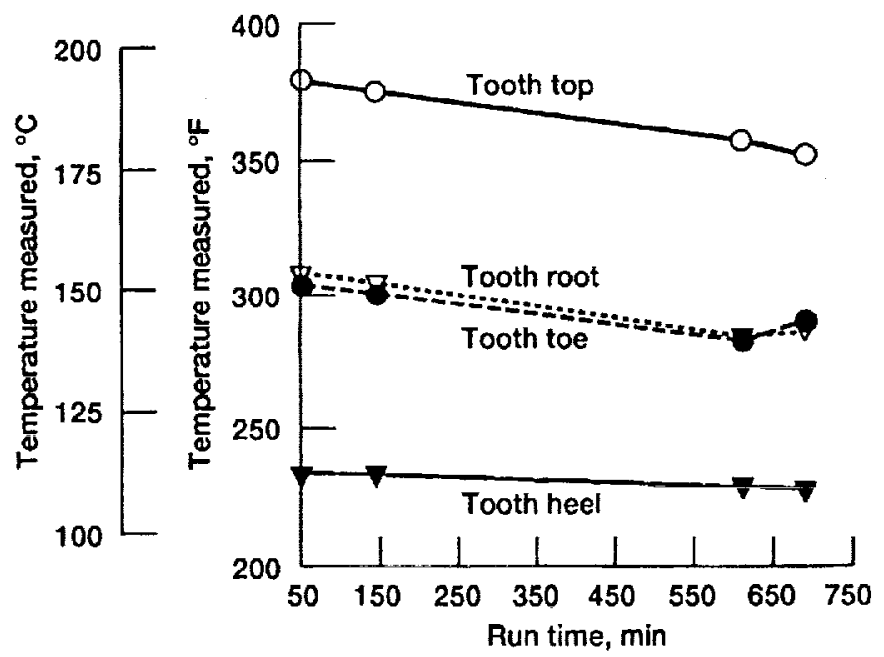

Figure 11.-Effect of run time on pinion temperature at $532 \mathrm{~kW}$ (714 hp) and lubricant flow rate $24 \mathrm{~cm}^{3} / \mathrm{sec}(0.38 \mathrm{gpm})$.
Therefore the steady-state measurements basically produced an intuitive outcome. Higher load and lower flow caused the pinion operating temperature to increase. The other important outcome was that into-mesh or out-of-mesh lubrication produced similar results. Based on these results out-of-mesh lubrication would be the prudent choice of lubricant location since the gears would not have to pump the oil trapped between the meshing teeth. A summary of the thermocouple measurements is shown in Table 4.

\section{TRANSIENT TEMPERATURE MEASUREMENT RESULTS}

The transient temperature measurements were made after the test assembly had come to equilibrium at a given set of conditions, just as the steady-state measurements were made. All transient data were taken viewing the test pinion. The infrared microscope was positioned such that the locations of measurement were on the pinion at approximately one-half the face width, $120^{\circ}$ out of mesh.

The output of the infrared microscope and a proximity probe were input to a dual-channel digital oscilloscope (Fig. (6)). Typical test data are shown in Fig. 12. The upper trace is from the infrared microscope and the lower is from the proximity probe. The purpose of the proximity probe was to establish a reference location in the data each time a pinion tooth tip passed the probe. The highest point of the lower curve corresponds to the tooth tip being directly over the proximity probe. Then the difference between the proximity probe and the infrared microscope alignment with the tooth tip is statically measured using a protractor attached to the end of the pinion shaft (Figs. 1 and 6). In this manner it was determined that the proximity probe led the infrared microscope by $23^{\circ}$.

Phase shifting of the infrared microscope and proximity probe were explored in a separate calibration. Both instruments are advertised to have a $15-\mathrm{kHz}$ and $20-\mathrm{kHz}$ response, respectively. A mechanical shutter, black-body source, and the proximity probe were used to simulate the transient test with the infrared microscope. The frequency range tested was from 540 to $1700 \mathrm{~Hz}$. Over this range there was no significant phase shift of the signals with respect to each other. However, while the signals, infrared and proximity probe, did not phase shift with frequency, the infrared signal itself is affected by the filtering used.

TABLE IV.-EXAMPLES OF STEADY-STATE DATA TAKEN $\left(38^{\circ} \mathrm{C}\left(100^{\circ} \mathrm{F}\right)\right.$ OIL IN TEMPERATURE.)

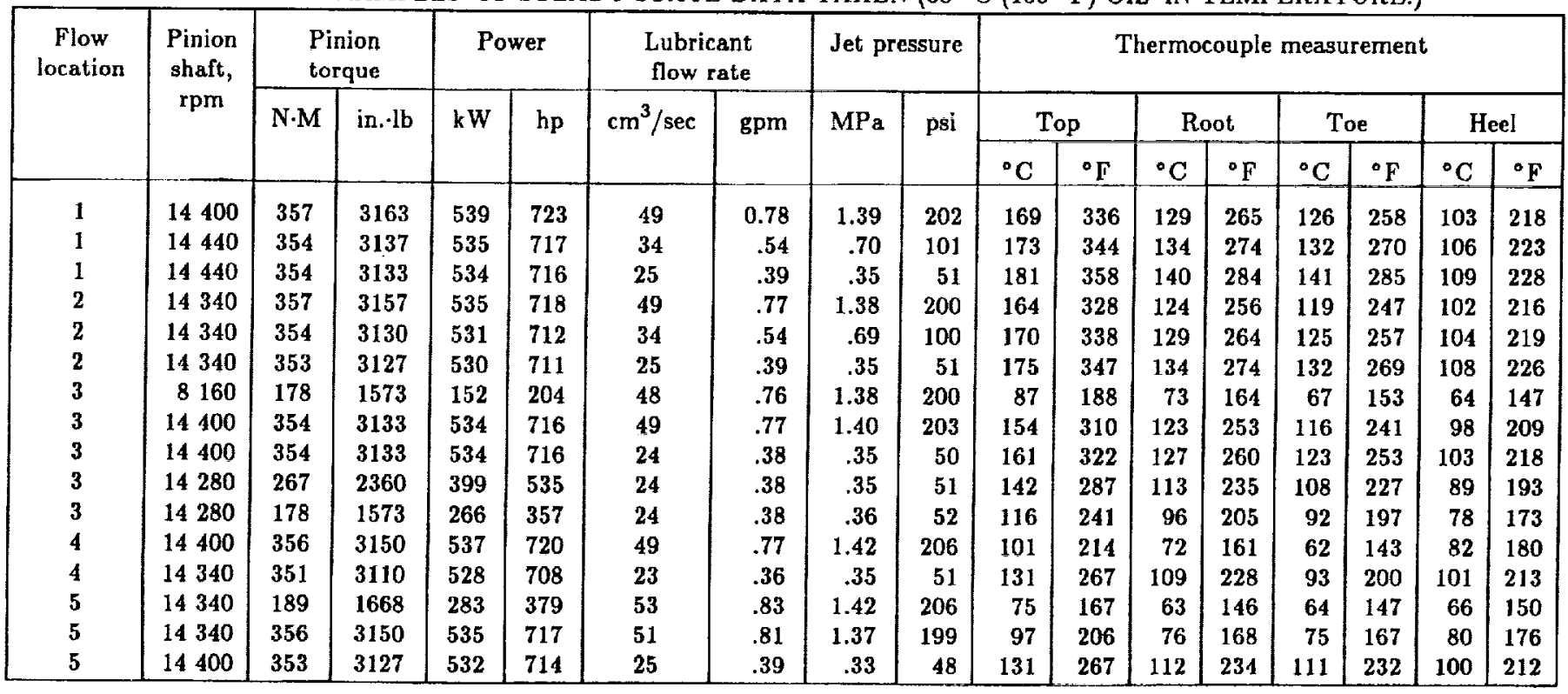




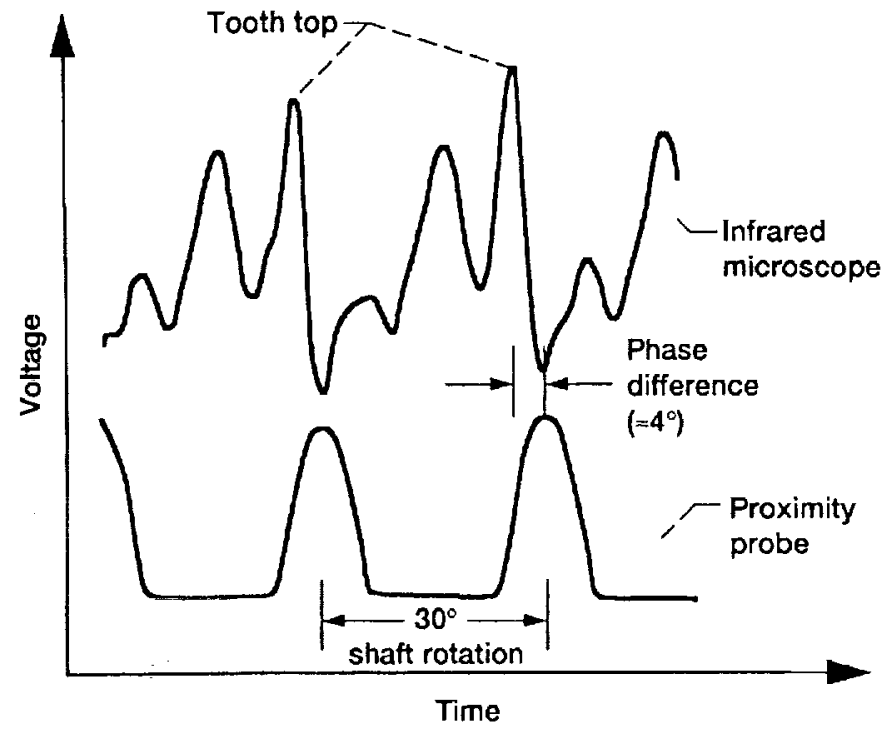

Figure 12.-Transient temperature measurement at pinion speed $14400 \mathrm{rpm}$, pinion torque $354 \mathrm{~N}^{*} \mathrm{~m}\left(3130 \mathrm{in}^{*} \mathrm{lb}\right)$, and lubricant flow rate of $25 \mathrm{~cm}^{3} / \mathrm{sec}(.39 \mathrm{gpm})$.

The infrared signal, filtered in the transient measurements, used a band pass of approximately $100 \mathrm{~Hz}$ to $20 \mathrm{kHz}$. The effect of filtering on the infrared signal was determined with respect to the proximity probe signal. Filtered signals using different band widths, were compared to the unfiltered raw data. Based on the filtering used in the test program, the experimental results showed a phase difference of approximately $3^{\circ}$. Utilizing this information, the location of the top of the tooth in the infrared signal can be correctly identified.

In Fig. 12 the angular rotation between proximity probe peaks is $30^{\circ}\left(360^{\circ} / 12\right.$ pinion teeth)). Therefore the tooth top in the infrared signal would be $7^{\circ}$ before the peak in the proximity probe signal based on the static measurement. Then accounting for the phase shift due to filtering, the net effect is that the infrared signals should lead the proximity signal by $4^{\circ}$. Thus, in Fig. 12, the temperature peak indicated corresponds to the tooth top. In Fig. 12 the voltage differential measured indicates a variation in the tooth surface temperature.

As mentioned earlier in the Calibration Section, the transient temperature measurement faces many obstacles. Many adjustments must be made to the measured data in order to account for all that is actually taking place. Measurements were made only at those jet locations where lubricant windage did not seriously affect the optical path between the pinion and the infrared microscope. A special viewing port was developed to keep lubricant off the sapphire window and out of the tube that extended through the test pinion measurement location.

As also discussed earlier, the window used for viewing, specimen emissivity, and oil film thickness all can affect the instrument's output. The emissivity needed for calculation purposes was found to be 0.37 based on the steady-state infrared microscope measurement and the bulk gear thermocouple measurement. The emissivity setting of the infrared microscope was varied when the steady-state measurement was made. From the values of bulk temperature and steady-state infrared measurement, including the attenuation due to the sapphire lens, the emissivity was found. The bulk gear temperature used was the average of the root and top of tooth thermocouples.
For the data shown in Fig. 12 the reference surface temperature of the pinion was $127^{\circ} \mathrm{C}\left(260^{\circ} \mathrm{F}\right)$ using the root thermocouple. This thermocouple was chosen as the reference temperature because it was the only one in this experiment that was attached to the surface and not buried below it. The measured total voltage differential was $0.096 \mathrm{~V}$ for Fig. 12. The effect of the window's attenuation on the signal was added to the measured quantity based on the calibration data.

To summarize the calculation procedure utilized for the transient measurements, Fig. 12 will be used as an example of the calculations performed. Based on the data shown in Fig. 12 and the calibrations that included attenuation due to the sapphire window, the actual peak-to-peak voltage was approximately $0.130 \mathrm{~V}$. Therefore the net radiance change, which was proportional to the voltage differ ential divided by the product of surface emissivity and the instrument manufacturer's calibration constant $(\Delta N=\Delta V /(\varepsilon \mathrm{k}) \varepsilon=0.37$; $\mathrm{k}=9.77\left(\mathrm{~V}^{*} \mathrm{ster}^{*} \mathrm{~cm}^{2} / \mathrm{W}\right)$, was calculated to be $0.036 \mathrm{~W} /\left(\mathrm{ster}^{*} \mathrm{~cm}^{2}\right)$. Since the radiance is a logarithmic function of temperature, the change in radiance or temperature change across the surface is related to the reference temperature level (Fig. 13)). In other words, if the change in radiance was kept constant, different reference temperatures would produce different temperature differentials. The radiance based on the reference gear temperature $\left(127^{\circ} \mathrm{C}\right)$ wias $0.0545 \mathrm{~W} /\left(\right.$ ster $\left.^{*} \mathrm{~cm}^{2}\right)$. Therefore with the above radiance changes, the maximum radiance in the transient infrared data of Fig. 12 was $0.0910 \mathrm{~W} /\left(\mathrm{ster}^{*} \mathrm{~cm}^{2}\right)$, and the corresponding temperature was $155^{\circ} \mathrm{C}$ $\left(311^{\circ} \mathrm{F}\right)$. The same procedure was done for several other test conditions and the results are shown in Table 5.

As can be seen Fig. 12, the gear tooth temperature varies substantially. In this report no attempt will be made to interpret this temperature variation along the profile. For now, it can only be said that this phenomena requires further study. For the measurement shown in Fig. 12 the tooth top thermocouple measured the temperature as $161^{\circ} \mathrm{C}\left(322^{\circ} \mathrm{F}\right)$. Therefore the results of the measurement and calculation procedures appear to be consistent but further study is required.

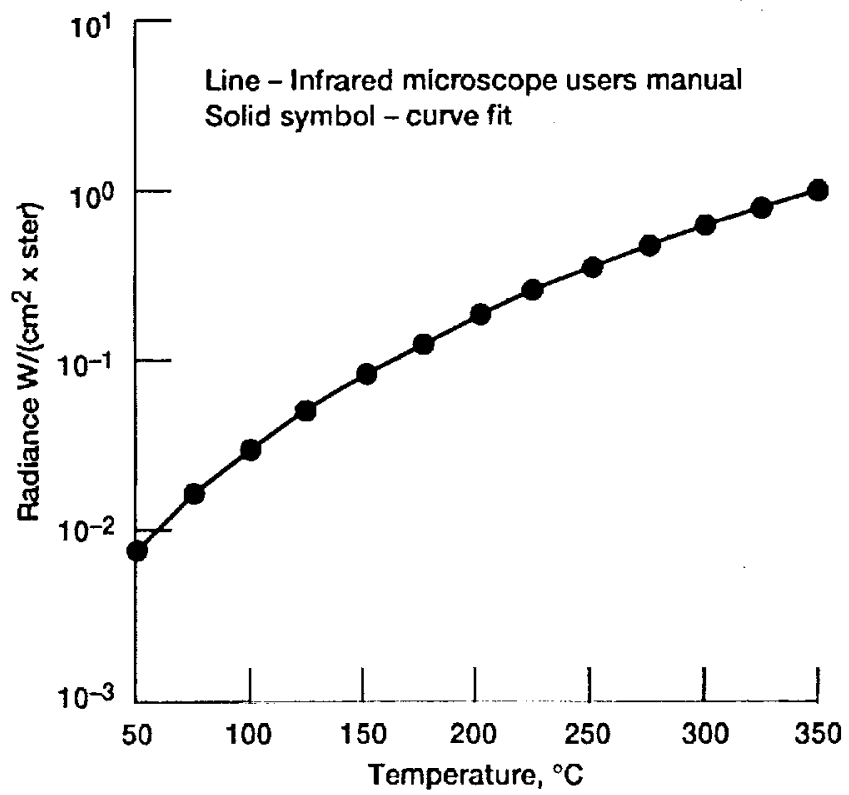

Figure 13.-Adjusted blackbody radiance as a function of temperature from Barnes Engineering Co., 1982. 
TABLE V.- TRANSIENT MEASUREMENTS

\begin{tabular}{|c|c|c|c|c|c|c|c|c|c|c|c|c|c|c|}
\hline \multirow[t]{3}{*}{$\begin{array}{c}\text { Jet } \\
\text { propulsion }\end{array}$} & \multicolumn{3}{|c|}{ Pinion } & \multicolumn{4}{|c|}{ Lubricant jet } & \multirow{3}{*}{$\begin{array}{c}\text { Adjusted } \\
\text { voltage } \\
\text { differential, } \\
\text { V }\end{array}$} & \multicolumn{4}{|c|}{ Thermocouple } & \multicolumn{2}{|c|}{$\begin{array}{c}\text { Infrared } \\
\text { maximum } \\
\text { temperature }\end{array}$} \\
\hline & \multirow[t]{2}{*}{$\begin{array}{l}\text { Speed, } \\
\text { rpm }\end{array}$} & \multicolumn{2}{|c|}{ Torque } & \multicolumn{2}{|c|}{ Pressure } & \multicolumn{2}{|c|}{ Flow } & & \multicolumn{2}{|c|}{$\begin{array}{l}\text { Root } \\
\text { reference }\end{array}$} & \multicolumn{2}{|c|}{ Top } & \multirow[t]{2}{*}{${ }^{\circ} \mathrm{C}$} & \multirow[t]{2}{*}{${ }^{\circ} \mathrm{F}$} \\
\hline & & $\mathrm{N} \cdot \mathrm{M}$ & in. $\cdot l b$ & $\mathrm{MPa}$ & psi & $\mathrm{cm}^{3} / \mathrm{sec}$ & $\mathrm{gpm}$ & & ${ }^{\circ} \mathrm{C}$ & ${ }^{\circ} \mathrm{F}$ & ${ }^{\circ} \mathrm{C}$ & ${ }^{\circ} \mathbf{F}$ & & \\
\hline 2 & 14400 & 357 & 3157 & 1.38 & 200 & 49 & 0.77 & 0.132 & 124 & 256 & 164 & 328 & 153 & 307 \\
\hline 2 & & 354 & 3130 & .35 & 50 & 25 & .39 & 0.170 & 134 & 274 & 175 & 347 & 166 & 331 \\
\hline 3 & & 354 & 3133 & 1.40 & 203 & 49 & .77 & 0.115 & 123 & 253 & 154 & 310 & 149 & 300 \\
\hline 3 & - & 354 & 3130 & .35 & 50 & 25 & .39 & 0.130 & 127 & 260 & 161 & 322 & 155 & 311 \\
\hline
\end{tabular}

\section{CONCLUSIONS}

The effects of lubricant jet placement, various lubricant flow conditions, and facility operational parameters on performance of aerospace spiral bevel gears were studied. The following general conclusions of the test results can be made:

1. Pinion steady-state tooth temperature were influenced by all the parameters under consideration.

2. Both into-mesh and out-of-mesh position produced the lowest pinion tooth temperatures. Both positions produced similar results for the same lubricant flow rate and load. However, out of mesh would be chosen for the given study as being the optimum position to avoid losses associated with pumping the lubricant out of the meshing zone.

3. Transient measurements were made and the surface temperature was found to vary a great deal over the pinion profile. This part of the effort requires further study to interpret all that transient signal can represent.

\section{REFERENCES}

Akin, L., Mross, J., and Townsend, D., 1975, "Study of Lubricant Jet Flow Phenomena in Spur Gears," Journal of Lubrication Technology, Vol. 97, No. 2, pp. 283-291.
Barnes Engineering Co., 1982, "Infrared Radiometric Microscope Model RM-2A," Instruction Manual, Stamford, Ct.

Chao, C., Baxter, M., and Cheng, H., 1981, “A Computer Solution for the Dynamic Load, Lubricant Film Thickness, and Surface Temperature in Spiral Bevel Gears," Advanced Power Transmission Technology, G.K. Fisher, ed., NASA CP-2210, pp. 345-363.

Doi, Y. et al., 1981, "On Bulk Temperature in High-Speed and Heavy-Duty Gears," Proceedings of the International Symposium on Gearing and Power Transmission, JSME, Tokyo, Japan, pp. 247.252.

Nieman, G. and Lechner, G., 1965, "The Measurement of Surface Temperatures on Gear Teeth," Journal of Basic Engineering, Vol. 87, No. 3, pp. 641-654.

Townsend, D., 1990, "Surface Pitting Fatigue Life of Non-Involute Low-Contact-Ratio Gears," NASA TM-103116.

Townsend. D. and Akin, L., 1981, "Analytical and Experimental Spur Gear Tooth Temperature as Affected by Operating Variables," Journal of Mechanical Design, Vol. 103, No. 1, pp. 219-226.

Turchina, V., Sanborn, D., and Winer, W., 1974, "Temperature Measurements in Sliding Elastohydrodynamic Point Contacts," Journal of Lubrication Technology, Vol. 96, No. 3, pp. 464-471. 


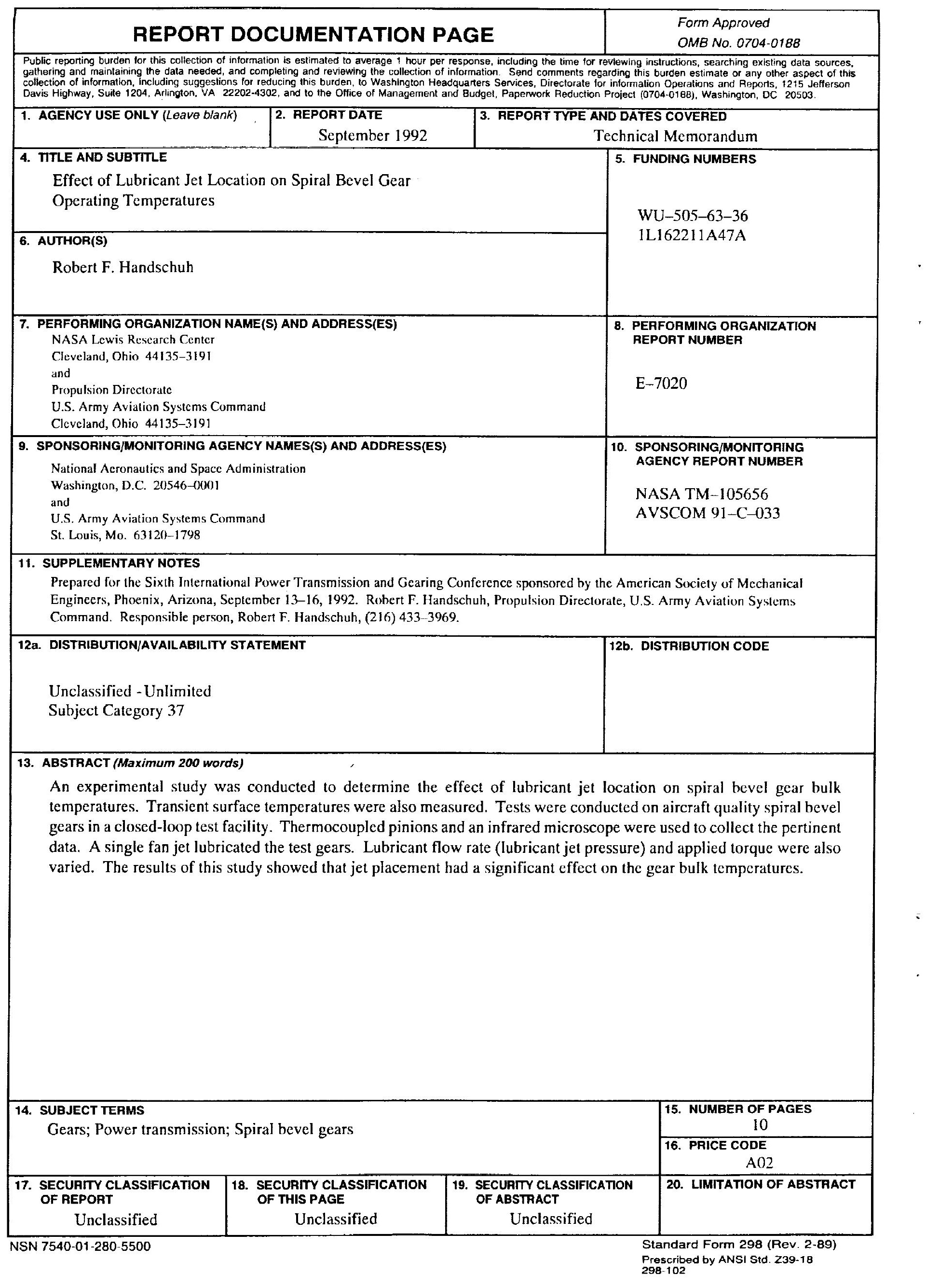

